\title{
S4 - Estimación y mapeo de dengue y chicungunya en Honduras 2015 utilizando sistemas de información geográfica
}

\author{
Lysien I. Zambrano*, Manuel Sierra, Bredy Lara, Iván Rodríguez-Núñez, Marco T. Medina, \\ Carlos Lozada-Riascos, Alfonso Rodríguez-Morales \\ Universidad Nacional Autónoma de Honduras
}

*Autor al que se dirige la correspondencia: lysien.zambrano@unah

\section{Resumen}

$\mathrm{C}$ Tomo parte del control y el riesgo para el dengue y chikungunya se trabaja en conjunto para analizar las implicaciones epidemiológicas de estas enfermedades a una escala regional y nacional. El objetivo fue estimar las tasas de incidencia de dengue y chikungunya en 2015 para Honduras y sus departamentos y desarrollar mapas epidemiológicos basados en SIG. Se realizó un estudio observacional retrospectivo tomando casos de dengue y chikungunya confirmados por clínica y laboratorio del sistema de vigilancia nacional para el año 2015 de 298 municipios, para estimaciones de tasas de incidencia anuales. Se utilizó el software de Microsoft Access ${ }^{\circledR}$ y Kosmo 3.0. Se reportaron 19,289 casos de dengue y 85,386 de chikungunya en Honduras. La mayoría de casos se registraron en las semanas epidemiológicas 25 y 27 respectivamente. Los mapas basados en SIG muestran que la incidencia del dengue es mayor en el sur, y chikungunya mayor en el centro-norte. Valle tiene la tasa más alta de incidencia de dengue (634 casos/100,000 habitantes); Francisco Morazán tiene 38.4\% del total de chikungunya (2,111 caso/100,000 habitantes). En los últimos dos años, las enfermedades por arbovirus han aumentado globalmente, especialmente en América Latina. Herramientas de salud pública para los análisis detallados, como el uso de mapas epidemiológicos basados en GIS permiten integrar las estrategias preventivas, así como políticas en salud pública, para el control conjunto de estas enfermedades transmitidas por vectores en Honduras.

Palabras claves: Arbovirus; mapa epidemiológico, enfermedades por vectore

\section{Abstract}

s part of the control and risk for chikungunya and dengue a work together has been stablished to analyze the A epidemiological implications of these diseases at regional and national levels. The objective is to estimate the incidence rates of dengue and chikungunya in 2015 to Honduras and its departments and develop epidemiological maps based on GIS. It was conducted an observational retrospective study. Dengue and chicungunya cases confirmed by clinical and laboratory from the national surveillance system for 2015 of 298 municipalities, estimates of annual incidence rates of both infections, using Microsoft Access ${ }^{\circledR}$ software and Kosmo 3.0. Cases of dengue $(19,289)$ and chikungunya $(85,386)$ were reported in Honduras. Most cases were reported in the 25 and 27 epidemiological weeks respectively. GIS-based maps show that the incidence of dengue is highest in the south, and chikungunya in the north-central. Valle has the highest incidence rate of dengue (634 cases/100,000 inhabitants) and Francisco Morazan has $38.4 \%$ of chikungunya (2,111 cases/ 100,000 inhabitants). In the past two years, arbovirus diseases have increased globally, especially in Latin America. Public health tools for detailed analysis, such as the use of epidemiological maps based on GIS can integrate preventive strategies and public health policies for joint control of these vector-borne diseases in Honduras.

Keywords: Arbovirus; vector-borne diseases, epidemiological maps 